„Kwartalnik Filmowy” nr 114 (2021)

ISSN: 0452-9502 (Print) ISSN: 2719-2725 (Online)

https://doi.org/10.36744/kf.748

(C) Creative Commons BY-NC-ND 4.0

Krzysztof Loska

Uniwersytet Jagielloński

https://orcid.org/0000-0003-4078-798X

\title{
Życie w cieniu elektrowni atomowej (Fukushima - dziesięć lat później)
}

\author{
Slowa kluczowe: \\ katastrofa \\ w Fukushimie; \\ skażenie \\ promieniotwórcze; \\ środowisko \\ naturalne
}

\begin{abstract}
Abstrakt
Tematem artykułu są filmy poświęcone skutkom skażenia promieniotwórczego, do którego doszło w marcu $2011 \mathrm{r}$. w wyniku awarii elektrowni atomowej Fukushima Daiichi. Wychodząc od koncepcji katastrofy w ujęciu francuskich filozofów - Jacques'a Derridy, Maurice'a Blanchota i Jeana-Luca Nancy'ego - autor skupia się na sposobach przedstawiania tego tematu w japońskich filmach dokumentalnych i fabularnych, których twórcy próbowali uczynić widzialnym to, co niewyobrażalne, mierzyli się z dylematami etycznymi oraz zastanawiali się nad kwestią odpowiedzialności człowieka za otaczający świat i klęski żywiołowe spowodowane jego działalnością.
\end{abstract}


Bycie widzem nieszczęść nawiedzających inne kraje jest jednym z najbardziej charakterystycznych przeżyć wspótczesności.

Susan Sontag, Widok cudzego cierpienia

Upłynęło dziesięć lat od wielkiego trzęsienia ziemi, które wywołało potężną falę tsunami i doprowadziło do awarii reaktorów atomowych w elektrowni Fukushima Daiichi (numer 1). Przez ten czas powstało kilkaset filmów dokumentalnych i kilkanaście fabuł pełnometrażowych, które w sposób dosłowny lub metaforyczny odnosiły się do wydarzeń z 11 marca 2011 r. Obrazy zniszczonych miasteczek, opuszczonych domów i zwierząt błąkających się po wyludnionych ulicach przekonują o sile żywiołów naruszających kruche poczucie bezpieczeństwa. Wielokrotnie powtarzane $\mathrm{w}$ mediach zdjęcia wody wdzierającej się na dziesiątki kilometrów w głąb lądu, pustoszącej wszystko i odbierającej ludziom cały ich dobytek wywołują szok i zapadają w pamięć, lecz równocześnie stają się czymś zwyczajnym i sprawiają, że oswajamy się z widokiem cudzego cierpienia, znieczuleni przez nadmiar zalewających nas informacji o skutkach katastrofy ${ }^{1}$.

Wiele zrealizowanych na ten temat filmów dokumentalnych pełni funkcję dydaktyczna, jest rodzajem ostrzeżenia na przyszłość, a zarazem zachętą do zastanowienia się nad kwestią odpowiedzialności. Jedni twórcy wykorzystują współczucie, gniew lub oburzenie dla osiągnięcia określonego efektu, drudzy pragną wzbudzić niepokój, przypominając o bezradności w obliczu sił natury, jeszcze inni wskazują na współudział ludzi w niszczeniu świata, w którym żyją. Wszyscy próbują z mniejszym lub większym powodzeniem, nakręcić kronikę czasów po kataklizmie, zaświadczyć o prawdzie, przechować pamięć o tragedii i ludziach, których ona dotknęła, wreszcie usytuować traumatyczne wydarzenia w szerszym kontekście historycznym i społecznym, tworząc w ten sposób narrację o cierpieniu oraz budując swoiste archiwum obrazów apokalipsy. Niełatwo odpowiedzieć na pytanie, kto może opowiadać o tej tragedii? Czy filmowcy, dramaturdzy i reporterzy mają prawo wypowiadać się w imieniu pokrzywdzonych, czy powinni raczej oddać głos ofiarom i ich bliskim?²

\section{Saigai riron (Teoria katastrofy)}

Uszkodzenie reaktorów w japońskiej elektrowni na powrót uczyniło zasadnym pytania sformułowane w ramach „krytyki nuklearnej”, której zarys przedstawił Jacques Derrida w wykładzie wygłoszonym na Uniwersytecie Cornella w 1984 r. ${ }^{3}$ Francuski filozof próbował zmierzyć się z widmem zagłady atomowej, przywołanym za sprawą nasilającego się na początku lat 80. ubiegłego wieku wyścigu zbrojeń. Chodziło mu, po pierwsze, o uzmysłowienie słuchaczom (i późniejszym czytelnikom), jak iluzoryczna jest nadzieja na przywrócenie utraconego porządku, po drugie zaś, o zwrócenie uwagi na apokaliptyczny horyzont, który odciska swoje piętno na teraźniejszości. Zastanawiając się nad wizualnymi reprezentacjami zagrożenia atomowego, należy uwzględnić nie tylko kwestię techniki oraz technologicznego przyspieszenia, jakie dokonało się wraz z rozwojem cywilizacyjnym, lecz również zmieniający się charakter stosunków łączących człowieka z naturą ${ }^{4}$.

Katastrofa odsłania to, co nie s a m o w i te w ludzkim życiu, co przerażające i obce, lecz równocześnie dobrze znane (choć wyparte ze świadomości). Tragedia 
Fukushimy przypomina zarówno awarię reaktora w Czarnobylu, jak i wcześniejsze o kilkadziesiąt lat eksplozje bomb atomowych w Hiroszimie i Nagasaki. W tym kontekście można przywołać słowa Maurice'a Blanchota, który w L'Écriture du désastre pisał, że katastrofa nigdy nie jest po prostu tym, czym jest, czyli wydarzeniem nieprzewidywalnym, bez precedensu, lecz zawsze jest powtórzeniem tego, co miało już miejsce i co zarazem zniweczyło możliwość przyszłości ${ }^{5}$. Powinniśmy zadać sobie pytanie, czy istnieje szansa na wypracowanie strategii pozwalającej na zachowanie tego, czego nie zdołaliśmy jeszcze zniszczyć, na przekształcenie stosunków łączących nas z innymi istotami żyjącymi i materią nieożywioną oraz nawiązanie nowych relacji etycznych, opartych na odpowiedzialności i solidarności międzygatunkowej.

Jean-Luc Nancy w eseju L'Équivalence des catastrophes (Après Fukushima) przy-

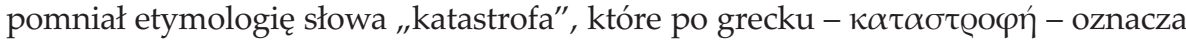
przewrót, lecz w kontekście tragedii antycznej wiąże się z oczyszczeniem, zaklinaniem, odreagowaniem i uwolnieniem ${ }^{6}$. Czas po katastrofie to okres tworzenia nowych warunków życiowych, dostrzeżenie powiązań istniejących pomiędzy różnymi systemami oraz refleksja nad skutkami naszych działań. Jak przekonuje Nancy, nie można już mówić o klęskach żywiołowych jako naturalnych kataklizmach, ponieważ wszystkie są wywoływane - czasem pośrednio - przez człowieka, a właściwie technikę, za pomocą której przekształca on naturę. Właśnie dlatego trzęsienie ziemi, tsunami i awaria reaktora są rozważane łącznie jako klęska w wymiarze społecznym, politycznym i egzystencjalnym. Ważną rolę odgrywa tu praca żałoby oraz związany $\mathrm{z}$ nią proces zapominania o bolesnej przeszłości oraz odbudowywania życia w taki sposób, jak gdyby - w przeciwieństwie do katastroficznego wybuchu, który odkrywat i odstaniat to, co uprzednio było ukryte i zasłonięte (na przykład radioaktywność uwięziona w ostonie reaktora) - należało zapomnieć lub „pogrzebać” sam fakt napromieniowania ${ }^{7}$.

\section{Saigai no hi (Dzień katastrofy)}

Nietrudno wyznaczyć początek nieszczęść, jakie dotknęły mieszkańców północno-wschodniego regionu Japonii (Tōhoku). 11 marca 2011 r. w godzinach popołudniowych doszło do trzęsienia ziemi o sile dziewięciu stopni w skali Richtera, po czym wezbrała wielka, sięgająca kilkunastu metrów fala, która uderzyła w wybrzeże i zalała rozległe tereny w prefekturach Iwate, Miyagi i Fukushima. W tym samym czasie nastąpiła awaria w elektrowni Fukushima Daiichi, wybudowanej na pograniczu miejscowości Ōkuma i Futaba, co doprowadziło do skażenia promieniotwórczego gleby, zbiorników wodnych, pól uprawnych i sadów położonych w promieniu kilkudziesięciu kilometrów od epicentrum ${ }^{8}$. Według oficjalnych danych liczba ofiar śmiertelnych przekroczyła 15 tysięcy, dwa i pół tysiąca osób uznano za zaginione, kilkaset tysięcy ludzi zostało pozbawionych dachu nad głową i zmuszonych do ewakuacji. Jeśli doliczyć do tego straty wśród zwierząt hodowlanych - zginęło 3 tysiące krów, 30 tysięcy świń i 600 tysięcy kurczaków oraz negatywny wpływ na cały ekosystem, to wówczas otrzymamy pełny obraz tragedii ${ }^{9}$. W ciągu kilku lat doliczono się 120 tysięcy „nuklearnych uchodźców”, którzy w nowych miejscach byli przyjmowani z rezerwą i obawami, mieli trudności z wynajęciem domu, ich dzieci prześladowano w szkole (co przypomina los ocalonych - hibakusha - z Hiroszimy i Nagasaki). 
Sytuacja w elektrowni pogarszała się z godziny na godzinę, najpierw doszło do awarii systemu chłodzenia, później pojawił się przeciek, wskutek którego nastąpiło obniżenie poziomu wody, co z kolei spowodowało wzrost ciśnienia wewnątrz reaktora. 12 marca w godzinach porannych kamery zarejestrowały serię wybuchów i władze centralne nie mogły już dłużej ukrywać zagrożenia, choć postanowiły przemilczeć niewygodne fakty. Zaproszeni do programów telewizyjnych eksperci tłumaczyli, że sytuacja jest opanowana, a dymy nad budynkami to jedynie para wodna. Kiedy następnego dnia doszło do eksplozji wodoru w trzecim reaktorze, jej skutki były widoczne z wielu kilometrów, dlatego rozpoczęto ewakuację personelu. Na miejscu pozostali jedynie ochotnicy, których prasa nazwała "Pięćdziesiątką z Fukushimy".

W kolejnych dniach uspokajające komunikaty rządowe na temat braku zagrożenia życia i zdrowia stawały się coraz mniej wiarygodne, toteż mieszkańcy ewakuowanych terenów stopniowo tracili nadzieję na powrót do domów, zwłaszcza że do opinii publicznej przedostały się informacje o nieszczelności powłoki jednego z reaktorów i wycieku substancji radioaktywnej, wskutek czego poziom skażenia w okolicy elektrowni kilkakrotnie przekroczył dopuszczalne normy. W ciagu pierwszych tygodni wysiłki podejmowane przez rząd japoński wydawały się powtórzeniem retoryki znanej z lat 80 . ubiegłego wieku, kiedy to po serii wybuchów w elektrowni atomowej w Czarnobylu i skażeniu atmosfery pyłem radioaktywnym urzędnicy ukrywali prawdę, wypierali się odpowiedzialności i ograniczali do podejmowania arbitralnych decyzji, które służyły utrzymywaniu społeczeństwa w niewiedzy, zgodnie z zasada, że nie należy ulegać panice i żyć normalnie ${ }^{10}$.

W japońskich mediach społecznościowych pojawiało się coraz więcej niepokojących sygnałów o ubocznych skutkach skażenia (wypadanie włosów, krwawienia, biegunka). Użytkownicy portali publikowali w sieci krótkie filmy z podróży po „strefie zakazanej” (keikai kuiki), posługiwali się licznikiem Geigera jako podstawowym narzędziem, podczas gdy telewizja publiczna wciąż przekonywała o nieszkodliwości promieniowania radioaktywnego ${ }^{11}$. W kolejnych latach sytuacja nie uległa poprawie, rządzący unikali wzięcia odpowiedzialności za tragiczne wydarzenia, dlatego mieszkańcy samodzielnie zaczęli się organizować w stowarzyszenia, które przeprowadzały testy skażonej gleby i wody, pisały petycje do lokalnych władz i przekonywały o konieczności ochrony dzieci przed chorobami popromiennymi.

Uszkodzenie reaktorów podważyło mit absolutnego bezpieczeństwa (anzen shinwa) japońskiej technologii atomowej, a zarazem wyznaczyło początek nowej epoki, określanej w prasie słowem saigo („,po końcu”). W lipcu 2012 r. komisja śledcza powołana do zbadania wypadku w elektrowni atomowej Fukushima Daiichi przedstawiła raport, z którego jednoznacznie wynikało, że odpowiedzialność za awarię w znacznej mierze ponoszą ludzie, nie siły natury, zlekceważono bowiem procedury i wcześniejsze ostrzeżenia, a przed opinią publiczną ukrywano rzeczywiste rozmiary katastrofy. Pomimo krytycznej oceny sformułowanej przez naukowców rząd uznał, że Japonia nie może zrezygnować z energetyki jądrowej, i przyjął nowe regulacje prawne ograniczające możliwość rozpowszechniania informacji zagrażających bezpieczeństwu państwa, czyli rozsiewania „niepotwierdzonych pogłosek" (fühyō higai). 


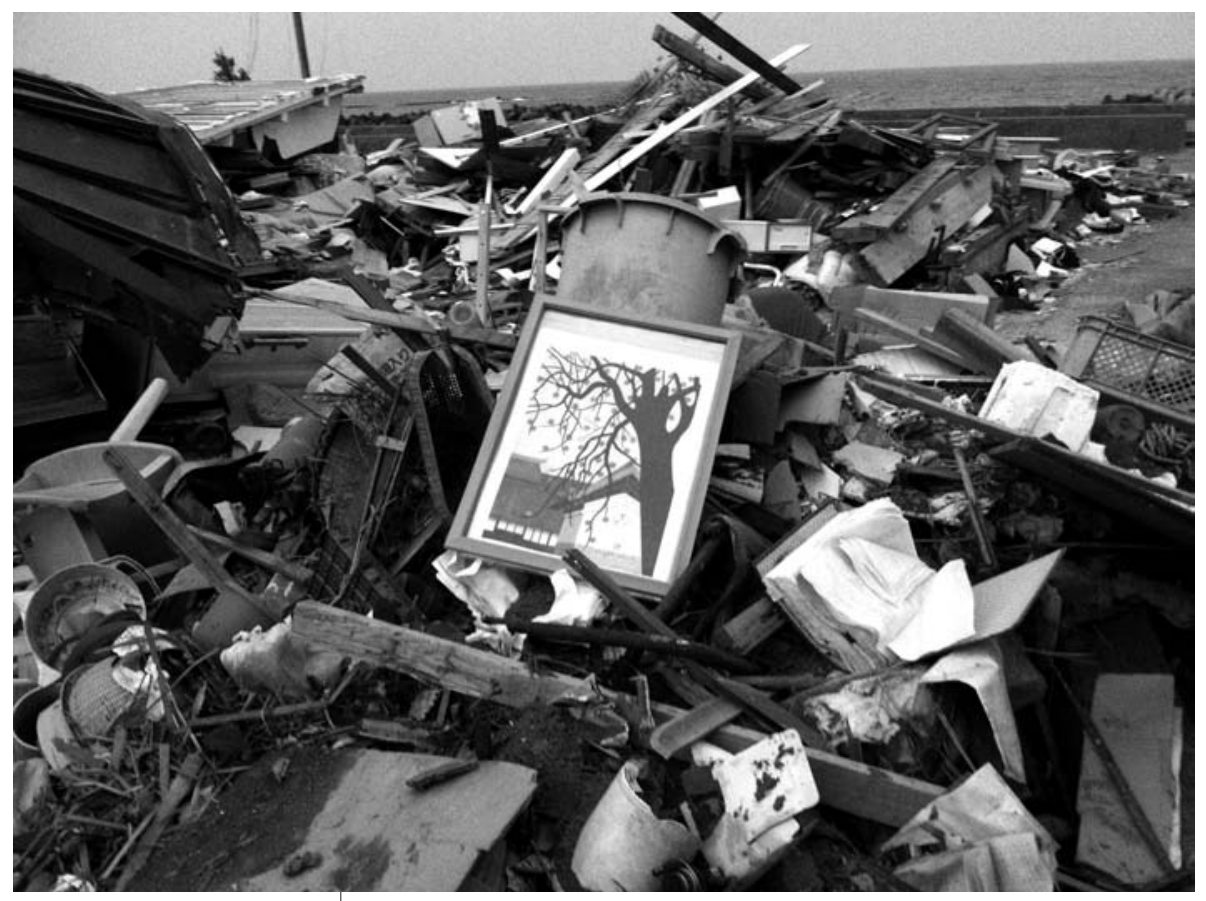

Tsunami i kwiat wiśni, reż. Lucy Walker (2011)

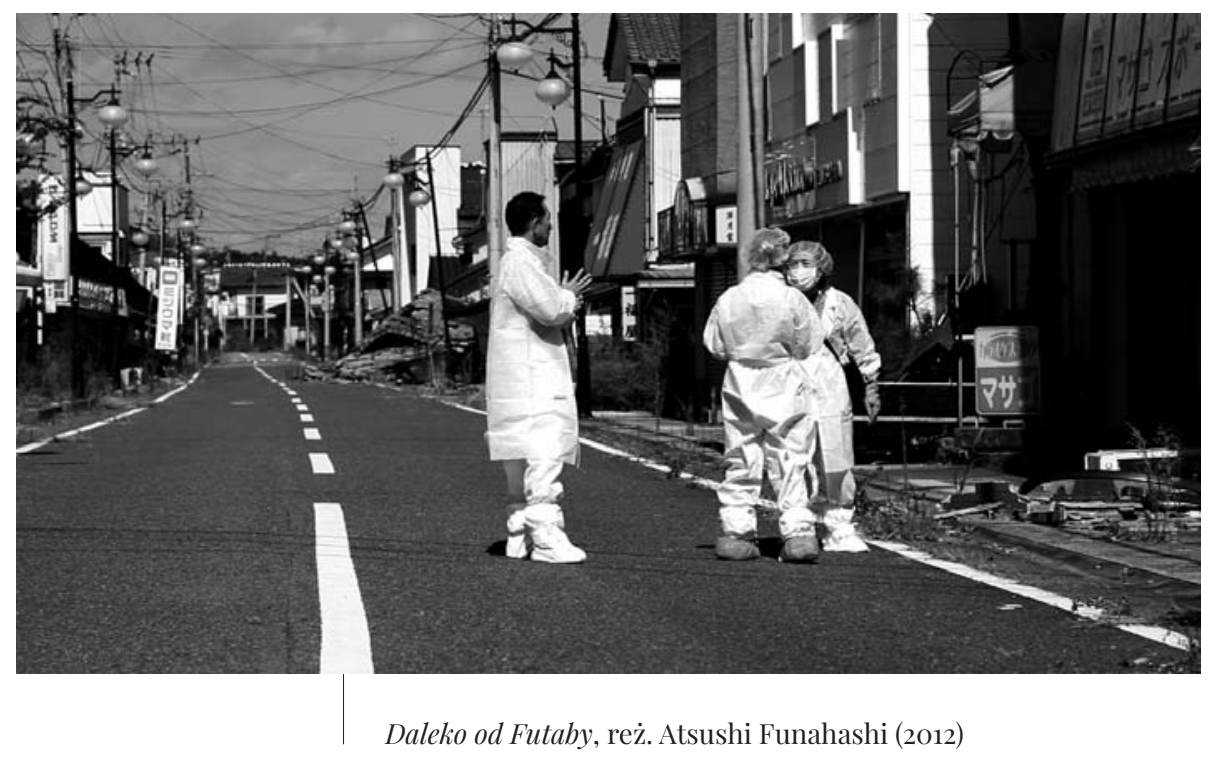




\section{Ganbare .Nippon! (Trzymaj się, Japonio!)}

Niedługo po trzęsieniu ziemi niezależni reporterzy i twórcy filmowi zaczęli rejestrować przebieg wypadków, dzięki czemu ich działalność wpisywała się w proces wytwarzania nowego rodzaju wiedzy, który Erin Manning nazywa research creation ze względu na wykorzystanie pozajęzykowych form komunikacji, głębokie zaangażowanie oraz uwzględnienie jako punktu wyjścia kontekstu społecznego dla działań teoretycznych i praktycznych ${ }^{12}$. O tragedii w Fukushimie zaczęto myśleć obrazami - to one przetrwały katastrofę i uczyniły widzialnym to, co niewyobrażalne. W pierwszych dniach po fali tsunami i uszkodzeniu reaktorów problemem dla filmowców stał się bezpieczny dostęp do obszarów zagrożonych, musieli również zmierzyć się z dylematami etycznymi i pytaniami o to, czy moralnie usprawiedliwione jest naruszanie prywatności pokrzywdzonych, którzy próbują otrząsnąć się z tragedii, oraz w jaki sposób powiązać ich osobiste przeżycia z szerszym kontekstem społecznym i politycznym.

W filmach dokumentalnych wyświetlanych w telewizji publicznej przeważały obrazy zespołów ratunkowych udzielających pomocy poszkodowanym, podkreślano w nich jedność narodową i akcentowano więzi łączące ofiary z resztą społeczeństwa ${ }^{13}$. Jednym $\mathrm{z}$ haseł, które opisywało strategię przetrwania w czasach po katastrofie, było ganbare - „trzymaj się!”, „daj z siebie wszystko!”. Słowo to pochodzi od rzeczownika gaman, który oznacza wytrzymałość, żywotność i wytrwałość, występuje także w japońskim buddyzmie zen, gdzie wiąże się z przekonaniem o tym, że cierpienie należy znosić z godnością. W istocie rządzący posługiwali się tym określeniem, aby skłonić ofiary trzęsienia ziemi i tsunami do pogodzenia się z przeznaczeniem i zaakceptowania trudnych warunków życiowych ${ }^{14}$. W środkach masowego przekazu dominowało przesłanie głoszące, że mieszkańcy regionu Tōhoku zostali ciężko doświadczeni przez los, jednak społeczeństwo japońskie jako całość wyjdzie z tego silniejsze, stąd obecność sloganów politycznych, formułowanych między innymi przez premiera Shinzō Abe, który zapowiadał realizację projektu „nacjonalizmu rekonstrukcyjnego" (fukkō nashonarizumu), mającego na celu podjęcie wspólnego wysiłku zmierzającego do odbudowy państwa ${ }^{15}$.

Pisząc o filmach wspierających oficjalną narrację, nie mam na myśli wyłącznie materiałów propagandowych, których autorzy przekonywali, że sytuacja jest opanowana i zachowano wszelkie środki bezpieczeństwa, lecz również pełnometrażowe utwory, nierzadko nagradzane na festiwalach, pozbawione wyraźnych akcentów krytycznych. Zazwyczaj dokumenty te powstawały przy finansowym wsparciu instytucji państwowych lub koncernów energetycznych. Ich twórcy skupiali się na organizacji pomocy, współpracy między lokalnymi władzami, przemysłem i mieszkańcami zagrożonych terenów, które poddano dekontaminacji i rewitalizacji. Przekonują o tym nawet projekty międzynarodowe, które opowiadają o odbudowywaniu życia, jak chociażby nominowany do Oscara film Tsunami i kwiat wiśni (Tsunami soshite sakura, reż. Lucy Walker, 2011) czy francusko-japoński dokument Po tamtej stronie chmur (Kiri no mukō no Yonaoshi 3.11 /Au-delà du nuage/, reż. Keiko Courdy, 2013).

Do pewnego stopnia unikanie otwartej krytyki politycznej dotyczyło również produkcji niezależnych, o czym świadczy dokument Hula Girls z Fukushimy 
(Ganbappe fura gāru! Fukushima ni ikiru - Kanojotachi no ima, reż. Masaki Kobayashi, 2011), opowiadający o tancerkach z Hawajskiego Centrum Kultury, które wyruszyły w tournée po kraju, żeby zebrać fundusze na remont budynku (działalność udało się wznowić pół roku po katastrofie). Tematem wyjściowym było przedstawienie więzi łączących bohaterki filmu z regionem oraz pokazanie, że ich los jest związany z elektrownią. Reżyser skupił się na powrocie do normalności, odbudowywaniu życia, jakie ludzie prowadzili przed katastrofa, oraz wysiłkach podejmowanych przez wspólnotę, by przetrwać trudne chwile (bez obarczania kogokolwiek odpowiedzialnością za trudną sytuację) ${ }^{16}$.

Znacznie mniej optymistyczny w wymowie był dokument Fukushima: wspomnienia o utraconym krajobrazie (Sōma kanka daiichibu: Ubawareta Tochino Kioku, reż. Yōju Matsubayashi, 2011), który powstał w pierwszych tygodniach kwietnia 2011 r. w prefekturze Fukushima. Reżyser rozmawiał w nim z Kyōko Tanaka, przedstawicielką rady miejskiej Minami-Sōma, na temat szabrowników, którzy okradali domy należące do ewakuowanych mieszkańców, ponieważ chciał zwrócić uwagę na to, co stało w sprzeczności z popularnymi hasłami o solidarności i pomocy niesionej poszkodowanym. Matsubayashi podważał tym samym mit japońskiego ładu, jednak i jemu nie chodziło o formułowanie jednoznacznych oskarżeń, lecz pokazanie, jak ludzie poradzili sobie w tych trudnych okolicznościach i w jaki sposób przepracowywali traumę.

Powyższe podejście do katastrofy odzwierciedla postawę przyjętą przez Japończyków po 11 marca, którą określa się mianem rezyliencji (jap. rejiriensu), rozumianej jako zdolność adaptacyjna człowieka, związana z umiejętnością radzenia sobie z przeciwnościami losu i dostosowywania się do zmieniających się warunków, dzięki czemu możliwe jest odzyskanie sił po wstrząsach psychicznych. Yotetsu Tonaki, japoński filozof i tłumacz, zastanawiał się nad sposobem, w jaki nowa strategia działania, mająca w przyszłości zapewnić społeczeństwu bezpieczeństwo, koresponduje z myślą Jeana-Luca Nancy'ego wyłożoną przez niego w eseju o Fukushimie, a zwłaszcza z pytaniami o to, czy uda się ponownie złożyć rozbite kawałki świata i czy można rozważać alternatywne warianty przyszłości w sytuacji, gdy katastrofa atomowa oznacza kres wszystkich przyszłych celów ${ }^{17}$.

\section{Tasha no kutsū e no manazashi (Widok cudzego cierpienia)}

W lutym 2012 r. na festiwalu filmowym w Berlinie wyświetlono dokument Daleko od Futaby (Futaba kara tōku hanarete, reż. Atsushi Funahashi, 2012), opowiadający o losach uchodźców z tytułowego miasteczka położonego w prefekturze Fukushima, których przesiedlono bezpośrednio po awarii elektrowni atomowej. Blisko półtora tysiąca osób umieszczono w starym budynku szkoły średniej i przez długi czas zabraniano im powrotu do domów ze względu na wysoki poziom skażenia promieniotwórczego. Reżyser obnaża postawę urzędników, których działania służyły jedynie stwarzaniu pozorów, że państwo opiekuje się pokrzywdzonymi, choć tak naprawdę nie zapewnia niezbędnej pomocy ${ }^{18}$. Większość czasu poświęca jednak na rozmowy z poszkodowanymi, ich rodzinami oraz burmistrzem miasteczka Katsutaką Idogawą który opowiada o tym, jak Futaba stała się „nuklearną wioską”. Funahashi nie proponuje widzowi pokrzepiającej historii 
o rekonstrukcji wspólnoty, lecz posługuje się narracją traumatyczną, opowiada o stracie i rozerwaniu więzi z bliskimi, o niemożności pogodzenia się z tragicznymi konsekwencjami nieprzewidzianych wydarzeń oraz życiu z piętnem przeszłości, które przed laty dotknęło ocalonych z Hiroszimy (reżyser należy do drugiego pokolenia tych, którzy przeżyli atak atomowy).

W tym miejscu należy zastanowić się nad kwestią rozważaną przez Jeana-Luca Nancy'ego w przywoływanym eseju L'Équivalence des catastrophes (Après Fukushima) i zadać pytanie o to, co znaczy żyć „po Fukushimie”. Nie chodzi przy tym wyłącznie o bezpośrednie skutki katastrofy - czyli następstwo czasowe - lecz całkowite zerwanie, które prowadzi do uświadomienia sobie faktu nieodwracalności tego, co się wydarzyło, a tym samym utraty wiary w bezpieczną przyszłość. Funahashi uchwycił to, co dostrzegł francuski filozof, że życie ludzkie, wraz z jego zdolnościa do myślenia, tworzenia i odczuwania radości, zostało sprowadzone do (...) otępienia, rozkojarzenia, przerażenia i beznadziejnego odrętwienia ${ }^{19}$.

W obliczu traumatycznego wydarzenia pojawia się potrzeba zastosowania mechanizmów obronnych, świadczących o elastyczności (résilience) i zdolnościach adaptacyjnych, które czasem przyjmują postać działań wspomagających, polegających chociażby na ograniczeniu kinowej dystrybucji filmów krytycznie oceniających przyjętą strategię radzenia sobie z tragedia, o czym świadczy przypadek Hitomi Kamanaki, reżyserki od początku kariery zajmującej się problematyką zagrożenia atomowego oraz skażenia promieniotwórczego ${ }^{20}$. Pokazy jej dokumentu zatytułowanego Przeżyć napromieniowanie (Naibu hibaku o ikinuku, 2012) organizowano zazwyczaj w szkołach, klubach i domach kultury. Można zgodzić się z interpretacją Hideakiego Fujiki, który stwierdził, że w filmie autorka próbowała odpowiedzieć na trzy zasadnicze pytania: jak groźna jest sytuacja dla mieszkańców skażonych terenów? jak udało im się przeżyć katastrofę? i wreszcie - w jaki sposób radzą sobie z problemami ${ }^{21} \mathrm{~W}$ pierwszej części filmu Kamanaka oddaje głos czworgu lekarzom, którzy omawiają wpływ promieniowania radioaktywnego na ludzkie życie oraz krytycznie oceniają działania podejmowane przez władze w pierwszych tygodniach po katastrofie. Ich wypowiedziom towarzyszą wykresy, plansze $z$ napisami i symulacje komputerowe, komentowane przez autorkę spoza kadru. Druga część jest poświęcona mieszkańcom skażonych trenów, z którymi rozmawia Kamanaka, jednak i w tym wypadku powraca sugestia, że ludzie powinni wspólnym wysiłkiem pokonać trudności, bez oczekiwania na pomoc rządowa, co do pewnego stopnia pozostaje zgodne z oficjalną narracją państwową.

Nieco inny charakter, ze względu na funkcję pejzażu w kreowaniu „apokaliptycznego imaginarium", ma Strefa zakazana (Mujin chitai, reż. Toshi Fujiwara, 2011). Film rozpoczyna się od panoramy miasteczka położonego nad brzegiem morza, całkowicie zniszczonego wskutek uderzenia fali tsunami. Zrujnowane domy pozostają na długo w pamięci, ale przede wszystkim są - jak zauważyła Rachel DiNitto - śladem po czymś, czego nie można już odzyskać i co na zawsze zostało utracone ${ }^{22}$. Głos spoza kadru potwierdza znaczącą rolę obrazów w konstruowaniu wyobrażeń o katastrofie: to, co nie zostało zarejestrowane, przemija, jak gdyby nigdy nie istniało. Fujiwara filmował w strefie zakazanej i na obszarach objętych całkowitą ewakuacja, mając nadzieję, że uda mu się zrozumieć tragiczne wydarzenia, nadać im jakiś sens, ale równocześnie pokazać fascynację obrazami zniszczeń. Czy jednak oglądanie zdjęć dokumentujących ludzką tragedię - i to 
oglądanie z bezpiecznej odległości (co jest naszym, czyli widzów, udziałem) - nie wywołuje moralnych wątpliwości? Czy nie pojawia się myśl, że być może - jak podpowiada Susan Sontag - nie mamy prawa przeżywać cudzego cierpienia z oddali, wyzutego ze swej surowej mocy $?^{23}$

Japoński reżyser próbował opowiedzieć o katastrofie nie tyle za pomocą słów (choć rozmawia z pokrzywdzonymi), ile za pośrednictwem obrazów przedstawiających tereny opuszczone przez człowieka, przypominające pejzaż postapokaliptyczny, dlatego w niektórych scenach rezygnuje z komentarza odautorskiego i na ścieżce dźwiękowej pozostawia jedynie szum morza i odgłosy wiejącego wiatru. Jeśli nawet kamera pokazuje miejsca wolne od zniszczeń, to uchwycone w oddali budynki elektrowni atomowej wskazują na niewidzialne zagrożenie, jakim jest promieniowanie radioaktywne, które zmusiło ludzi do opuszczenia domów rodzinnych. Sielankowe widoki nieskażonej natury, wzgórz porośniętych drzewami i pól uprawnych są jedynie złudzeniem, ponieważ przypominają o tym, co zostało utracone. Tym, co pozostało po katastrofie, jest „ziemia nie do życia" - świat, w którym próżno szukać tego, co znane i swojskie, a co zostało zastąpione przez zaburzony krajobraz - by użyć określenia Aleksandry Brylskiej - będący znakiem postpamięci, odbiciem afektywnego wybrakowania, które zdominowało doświadczenie awarii ${ }^{24}$.

Toshi Fujiwara nie pokazuje w swoim filmie utopijnej wizji przyrody powracającej do swego pierwotnego stanu, odtwarzającej wcześniejsze formy i samoregulującej się, jaką proponuje Keijirō Suga we Wspomnieniu wody, wspomnieniu ziemi (Mizu no kioku, tsuchi no kioku: Minami sōma kara, 2016), do którego zdjęcia powstały w prefekturze Fukushima, w regionie objętym ewakuacją ${ }^{25}$. Japoński poeta i artysta wizualny postanowił uchwycić proces przyspieszonego rozwoju fauny i flory, rewitalizacji skażonego ekosystemu, w którym „dzika natura” staje się symbolem odrodzonego życia, a przez to gwarancją jego ciągłości. Mniejszą rolę odgrywa w tym procesie człowiek jako siła sprawcza, "zarządzająca" przyroda, organizująca jej funkcjonowanie i podporządkowująca ją sobie, większą natomiast zjawiska niezależne od czynnika ludzkiego, potwierdzające nieprzewidywalność wzrostu pod wpływem promieniowania oddziałującego na organizmy roślinne i zwierzęce. Obrazy „radioaktywnego życia” stanowią odbicie witalistycznej filozofii autora oraz - jak się wydaje - potwierdzają jego tezę, że życie przetrwa w każdych warunkach, podczas gdy niekontrolowane mutacje powstałe w niestabilnym środowisku mogą okazać się wartością samą w sobie.

\section{Dōbutsu to hito (Zwierzęta i ludzie)}

W przywołanym przeze mnie filmie Daleko od Futaby Atsushi Funahashi opowiadał o mieszkańcach ewakuowanych z zagrożonej miejscowości, lecz w jednej ze scen poruszył temat, który odegrał ważną rolę w kilku innych dokumentach na temat Fukushimy, mianowicie zwrócił uwagę na tragiczny los zwierząt hodowlanych pozostawionych bez opieki. Reżyser rozmawiał z Masamim Yoshizawa, który zignorował nakazy urzędników i nie zgodził się na opuszczenie gospodarstwa, ponieważ chciał uratować swoje krowy przed cierpieniem i śmiercią głodową. Nie mogę sprzedać tych krów, choć utrzymywanie ich i karmienie wiąże się $z$ wydatkami. Jaka mam $z$ tego korzyśćc Byłem w rozterce, ale podjątem decyzje 
i postanowiłem, że pozwolę tym krowom żyć. Mój los jest zwiazany z ich losem. Zwierzęta te - podobnie jak wszyscy ocaleni ludzie - są żywym dowodem na to, co się stało, i na swój sposób protestuja przeciw nuklearnym wypadkom. Nie chodzi o sentymentalne uczucie, jakim darzymy zwierzęta domowe, lecz o utożsamienie się na głębszym poziomie - uważa Nicole Shukin - w powinowactwie śmierci ${ }^{26}$.

W słowach rolnika z regionu Fukushimy można dostrzec zapowiedź postawy nieantropocentrycznej, zgodnie z którą zwierzęta są traktowane jako "osoby", są bowiem istotami społecznymi, zdolnymi do nawiązywania relacji z przedstawicielami innych gatunków. Temat krów skażonych wskutek napromieniowania powrócił w filmie Tamotsu Matsubary $O \dot{z} y c i u$ z napromieniowanymi krowami (Hibaku ushi to ikiru, 2016), choć reżyser skupił się na postaci hodowcy, Fumikazu Watanabe, który opowiada o swojej pracy i relacjach łączących go ze zwierzętami. Mężczyzna przekonuje, że nie powinniśmy patrzeć na nie wyłącznie z punktu widzenia ich użyteczności dla przemysłu spożywczego, ale uwzględnić samo życie. W ten sposób zbliżamy się do kwestii podejmowanych przez Donnę Haraway w Manifeście gatunków stowarzyszonych, w którym jedna z głównych przedstawicielek filozofii posthumanistycznej pyta o to, jaką etykę i politykę prowadzącą do rozkwitu inności można wyprowadzić z poważnego podejścia do związków ludzi i zwierząt ${ }^{27}$.

Odpowiedzi na to pytanie szuka Masanori Iwasaki, który w latach 2013-2017 nakręcił serię dokumentów pod wspólnym tytułem Fukushima: zapis życia (Fukushima: ikimono no kiroku). Reżyser kieruje obiektyw kamery na zwierzęta pozostawione w strefie skażonej, chcąc w ten sposób zwrócić uwagę na istoty, które nie mogły opowiedzieć o swoim cierpieniu. Iwasaki zdecydował się na porzucenie stanowiska antropocentrycznego, zgodnie z którym zwierzęta służą wyłącznie przedstawieniu losu ludzkiego, i zamiast tego przyjął założenie, że są one podmiotami autonomicznymi, czującymi i świadomymi, obdarzonymi sprawczością ${ }^{28}$. Japońskiemu dokumentaliście chodziło o pokazanie wpływu promieniowania radioaktywnego na wszystkie stworzenia będące „żywymi świadkami” tragicznych wydarzeń, dlatego oglądamy krowy ze skórą pokrytą dziwnymi plamami oraz cielaki, które przyszły na świat niewidome ${ }^{29}$.

Omijanie pułapek antropomorfizacji oraz unikanie pokusy prowadzenia sentymentalnego dyskursu na temat zwierząt wyróżnia nie tylko Iwasakiego, ale także Yōju Matsubayashiego, który w Koniach z Fukushimy (Matsuri no uma, 2013) pokazał traumatyczne doświadczenie katastrofy przez pryzmat koni uwięzionych w stadninie położonej w strefie zakazanej. Ich właściciel, pan Tanaka, od lat szkolił je do udziału w dorocznym festiwalu w Minami-Sōma, który był jedną z głównych atrakcji turystycznych regionu, lecz po awarii w elektrowni atomowej został zmuszony do opuszczenia skażonego terenu. Po pewnym czasie otrzymał zezwolenie na krótkoterminowy powrót do gospodarstwa, gdzie znalazł zwierzęta na skraju śmierci głodowej. Reżyser postanowił opowiedzieć o międzygatunkowej solidarności i tak tłumaczył przesłanie swojego filmu: Pomimo że nie mówiliśmy tym samym językiem, to odkryłem, w jaki sposób konie wyrażaja swoje emocje za pomoca ciała. Kiedy zaczałtem je filmować, zaakceptowały mnie, i wówczas pomyślatem, że w ich wielkich oczach można zobaczyć odbicie tego, co myśla o człowieku inne zwierzęta. Mój film opowiada o powrocie do zdrowia, lecz dotyczy także przemystu hodowlanego, czyli tego, jak ludzie zarabiaja na życie, wykorzystując konie. Mówiąc o losie zwierząt, starałem się obnażyć 
hipokryzje społeczeństwa, które swój dobrobyt oparto na energii jądrowej, i przez historię koni przestrzec przed ludzka chciwościa i arogancja $a^{30}$.

Odejście od postawy antropocentrycznej wyraźnie podkreśla Daisuke Shishido w filmie Psy, koty, ludzie i... 2. Wielkie Trzęsienie Ziemi i zwierzęta (Inu to neko to ningen to. 2. Dōbutsutachi no daishinsai, 2013), traktując wszystkich swoich bohaterów jak osoby, istoty czujące i dotknięte przez tragedię. Reżyserowi udało się uchwycić nie tylko zwierzęcy punkt widzenia - by posłużyć się tytułem książki Érica Barataya - lecz także ukazać skomplikowane relacje między ludźmi i gatunkami stowarzyszonymi, przekonująco opowiedzieć o zdolności do współdzielenia przeżyć przez człowieka i zwierzęta domowe. Daisuke Shishido przedstawia historię weterynarzy prowadzących schroniska dla zwierząt w regionie Fukushimy, wolontariuszy pracujących w organizacjach pomocowych oraz zwykłych mieszkańców opiekujących się porzuconymi kotami (jak pan Kogura), ale tak naprawdę podąża z kamerą za zwierzętami. To one prowadzą go do ludzi i - jak ujmuje to Beata Kubiak Ho-Chi - sprawiaja, że kobiety i mężczyźni, porażeni tragedia, niepotrafiacy znaleźć sobie miejsca wśród zgliszcz tego, co jeszcze niedawno było ich normalnym życiem, sa w stanie odnaleźć choćby chwilowa równowagę i spokój. Niektórzy z nich uzmystawiaja sobie, jak ważni byli dla nich ich podopieczni i jak trudno jest pogodzić się z ich nagła śmiercia $a^{31}$. W niemal wszystkich wspomnianych dokumentach powracają obrazy umierających z głodu zwierząt i na wpół zdziczałych psów błąkających się po ruinach miasta, które zmuszają do zastanowienia się nad odpowiedzialnością człowieka za los nie-ludzkich stworzeń.

\section{Kibō no kuni (Kraina nadziei)}

O ile filmów dokumentalnych powstało kilkaset, o tyle fabuły poświęcone tragedii Fukushimy należały do rzadkości, ponieważ reżyserom nie udawało się znaleźć właściwej formy pozwalającej na przedstawienie traumatycznych wydarzeń oraz uchwycenie związku między osobistymi przeżyciami bohaterów a doświadczeniem zbiorowym, o czym przekonują zarówno alegoryczne opowieści w rodzaju Oczek meduzy (Mememe no kurage, reż. Takashi Murakami, 2013) czy Godzilli (Shin Gojira, reż. Hideaki Anno, Shinji Higuchi, 2016) ${ }^{32}$, jak i fabularyzowane rekonstrukcje odtwarzające przebieg wypadków z marca 2011 r., na przykład Fukushima 50 (reż. Setsurō Wakamatsu, 2020), w której dominuje pochwała bohaterskiej postawy pracowników elektrowni, z narażeniem życia biorących udział w akcji ratunkowej. Próbę włączenia jednostkowych wspomnień w społeczne ramy pamięci podjął Makoto Shinozaki w dwóch filmach: Od tamtej pory (Arekara, 2013) i Sharing (2014), w których wyraził przekonanie, że sztuka może pomóc w uporaniu się ze stratą i przepracowaniu traumatycznych doświadczeńn ${ }^{33}$.

Jednym z pierwszych reżyserów mających odwagę podjąć się trudnego tematu katastrofy był Sion Sono, który kilka miesięcy po trzęsieniu ziemi przystąpił do realizacji Krainy nadziei (Kibō no kuni, 2012), filmu wyróżnionego na festiwalu w Toronto, lecz odrzuconego przez japońskich krytyków i publiczność ${ }^{34}$. Historia rozgrywa się kilka lat po tragicznych wydarzeniach z marca 2011 r. w fikcyjnej prefekturze Nagashima. Reżyser opowiada o losach dwóch rodzin żyjących od pokoleń w wiosce położonej w cieniu wielkiej elektrowni atomowej. Yōichi (Jun Murakami) i Izumi Ono (Megumi Kagurazaka) pracują w gospodarstwie rolnym 


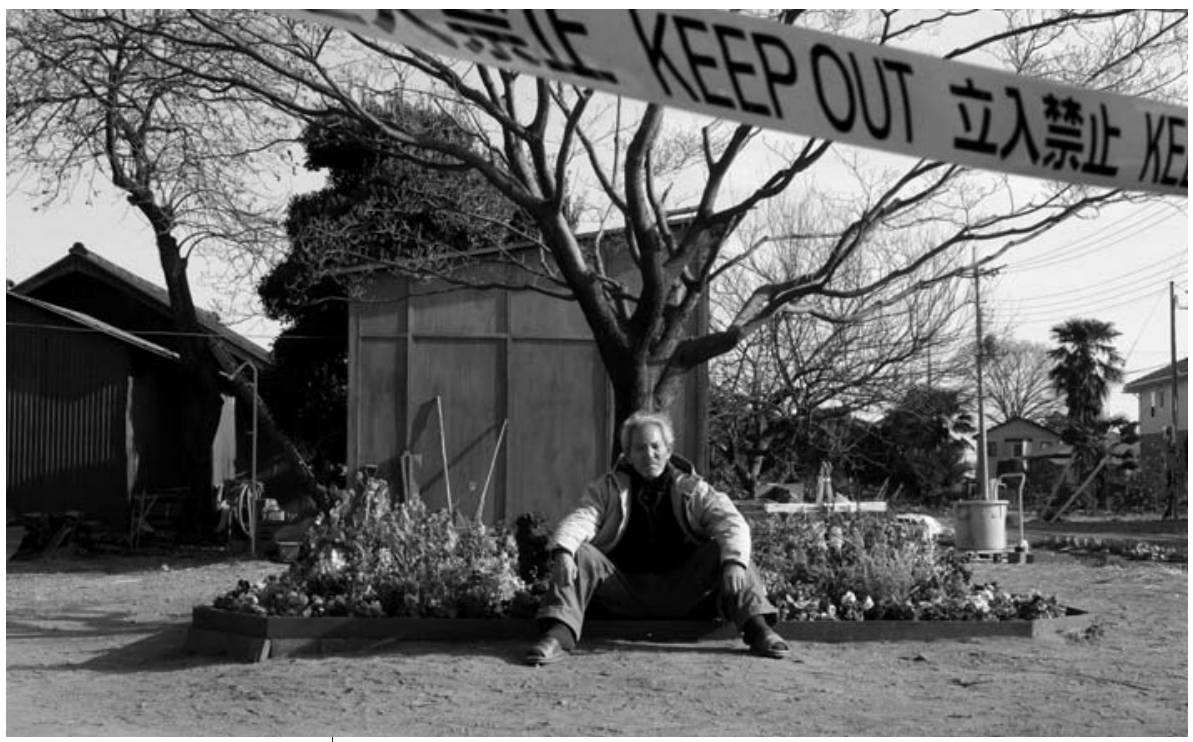

Kraina nadziei, reż. Sion Sono (2012)

ojca, z rodzicami mieszkają również ich sąsiedzi, Mitsuru (Yutaka Shimizu) i Yōko Suzuki (Hikari Kajiwara). Dzień, w którym dochodzi do trzęsienia ziemi, uderzenia fali tsunami i awarii reaktora, całkowicie zmienia ich życie i rozrywa dotychczasowe więzi. Służby porządkowe wyznaczają strefę skażenia promieniotwórczego biegnącą przez środek miejscowości, po czym jednym nakazują natychmiastową ewakuację, drugim zaś gwarantują bezpieczeństwo. Nie wierząc w zapewnienia lokalnych urzędników, Yasuhiko Ono (Isao Natsuyagi) prosi syna i synowa, aby opuścili dom i wyjechali na południe, zwłaszcza że młoda kobieta spodziewa się dziecka. Od tej chwili akcja rozgrywa się równocześnie w kilku miejscach: opuszczonym budynku szkolnym przekształconym w tymczasowy ośrodek dla ewakuowanych, w mieście, do którego przenieśli się Yōichi i Izumi, oraz w Nagashimie, gdzie pozostał Yasuhiko, by opiekować się chorą na alzheimera żoną i doglądać zwierząt w gospodarstwie.

Nieograniczony wymogami filmu dokumentalnego, Sion Sono posłużył się satyrą i groteska, by zdemaskować nieudolność władz, których absurdalne decyzje nie były w stanie nikomu zapewnić bezpieczeństwa, i ukazać, jak fatalną rolę odegrały środki masowego przekazu w pierwszych dniach po katastrofie. Wielu dziennikarzy ignorowało doniesienia o potencjalnym zagrożeniu, przekonywało ludzi do spożywania lokalnych produktów, wręcz zachęcało do zwiększenia konsumpcji ${ }^{35}$. Potwierdzają to przebitki z wiadomości telewizyjnych, w których dominują slogany w rodzaju ganbarō Nagashima! („trzymaj się, Nagashimo!”) oraz pojawiają się wypowiedzi prezenterów zapewniających o nieszkodliwości promieniowania radioaktywnego i sugerujących, że nie należy ulegać masowej histerii ani wierzyć w niesprawdzone pogłoski.

Japoński reżyser konsekwentnie obnaża iluzję solidarności, którą lansowały media, ponieważ uchodźcy ze skażonych obszarów nie byli nigdzie przyjmowani z otwartymi ramionami, lecz traktowani z podejrzliwością, a nawet jawną wrogo- 
ścią. Chłopcy wracający ze szkoły wyśmiewają się z kolegi pochodzącego z Nagashimy, pracownik stacji benzynowej odmawia obsługi „radioaktywnego samochodu", ludzie w miasteczku z wyraźną niechęcią odnoszą się do środków bezpieczeństwa, jakie stosuje Izumi pod wpływem lektury licznych książek. Kobieta najpierw kupuje jednorazowe maseczki, potem wkłada specjalny kombinezon ochronny, w którym idzie na zakupy, i sprawdza wszystkie towary licznikiem Geigera. W jej zachowaniu można dostrzec podobieństwo do postawy „neurotycznej”, jaka wyróżniała bohatera filmu Akiry Kurosawy Żyję w strachu (Ikimono no kiroku, 1955), który za wszelką cenę chciał uchronić rodzinę przed zagładą atomową. Obaj twórcy pragnęli pokazać stopniowy proces „nuklearyzacji” współczesnej kultury oraz uchwycić obraz społeczeństwa żyjącego w cieniu skażenia promieniotwórczego. W Krainie nadziei wybrzmiewa diagnoza stawiana przez wielu innych reżyserów, że jedyną szansą na ocalenie życia w sytuacji, gdy zawodzą wszystkie instytucje państwowe, jest poleganie na własnych siłach i na pomocy najbliższych. Idea „odpowiedzialności za siebie” (jikosekinin), która w świecie po katastrofie przybrała postać podstawowej strategii przetrwania, jest przyjmowana przez ludzi opuszczonych i pozbawionych realnego wsparcia ze strony władz ${ }^{36}$.

Finałowe sceny rozgrywają się na nadmorskiej plaży, gdzie Yōichi i Izumi spotykają rodzinę z dziećmi, jednak ich szczęście jest wyłącznie złudzeniem, ponieważ mąż ukrywa przed żoną prawdę o tym, że nie ma ucieczki przed radioaktywnym promieniowaniem, że skażony jest cały kraj. Katastrofa w Fukushimie zdarła zasłonę, za którą skryło się japońskie społeczeństwo po II wojnie światowej, i unieważniła obietnicę bezpieczeństwa. Jak żyć po wyczerpaniu się nadziei pyta Sion Sono - w obliczu zmierzchu cywilizacji, kiedy nie można marzyć ani o nostalgicznym powrocie do domu i odzyskaniu dawnego życia, ani o stabilnej przyszłości dla następnych pokoleń? Krytyka nuklearna udowodniła, że apokalipsa już się dokonała, nie przyniosła jednak ze sobą obietnicy odrodzenia, ponieważ była apokalipsa bez wizji, bez prawdy, bez objawienia ${ }^{37}$. Świadczą o tym sceny poprzedzające końcową sekwencję, w których Yōko i Mitsuru spacerują po bezludnych terenach strefy zamkniętej, przyglądają się opuszczonym budynkom przemysłowym, zniszczonym domom, wrakom samochodów i bezpańskim psom szukającym pożywienia.

Sion Sono pokazał stopniową przemianę idyllicznej scenerii rolniczego regionu północno-wschodniej Japonii w postapokaliptyczny pejzaż będący odzwierciedleniem zniszczonego porządku społecznego i rozpadających się więzi międzyludzkich. Podobnie jak twórcy dokumentów poświęconych Fukushimie, pragnął uporać się z traumatycznym doświadczeniem katastrofy, zmierzyć z obrazami cudzego cierpienia i zastanowić nad skutkami urzędniczej niekompetencji oraz brakiem odpowiedzialności. Czy za pomocą obrazów uda się przekonać kogokolwiek do rezygnacji z energii atomowej, czy raczej świadomość problemów związanych ze składowaniem odpadów promieniotwórczych i obecnością pyłu radioaktywnego $\mathrm{w}$ atmosferze, w morzach i oceanach jest przez nas konsekwentnie wypierana? Wszystkie omawiane przeze mnie filmy poruszają temat katastrofy ekologicznej, skażenia środowiska i zagrożeń z tym związanych, ale przede wszystkim zachęcają do zastanowienia się nad konsekwencjami naszych czynów i do odpowiedzi na pytanie o zakres odpowiedzialności za otaczający świat. 
${ }^{1}$ Mimo że w światowych relacjach $\mathrm{z}$ katastrofy w Fukushimie przeważały obrazy zniszczeń, to jednak pojawiały się również reportaże przekonujące o spokoju i opanowaniu mieszkańców, ich oswojeniu z żywiołami, co stanowiło kolejny wariant stereotypu „azjatyckiej mentalności", dominujący w zachodnich mediach. Por. K. Maurer, Translating Catastrophes: Yoko Tawada's Poetic Responses to the 2011 Tōhoku Earthquake, the Tsunami, and Fukushima, "New German Critique" 2016, t. 43, nr 1, s. 164-175.

${ }^{2}$ Wątpliwości etyczne pojawiły się po premierze jednego z pierwszych dokumentów, które wyświetlono na październikowym festiwalu w Yamagacie. Twórcom 311 (reż. Tatsuya Mori, Yōju Matsubayashi, Takuji Yasuoka, Takeharu Watai, 2011) zarzucono żerowanie na nieszczęściu, naruszanie prawa do prywatności i filmowanie bez zgody pokrzywdzonych. Największe zastrzeżenia wzbudziły sceny finałowe, nakręcone z ukrytej kamery, w których Mori pyta kobiety o śmierć uczniów szkoły podstawowej w Ōkawie. W następnych ujęciach obiektyw jest skierowany na grupę mężczyzn, którzy przyjechali, aby zidentyfikować ciała swoich dzieci. Kamera narusza sferę intymności, jest narzędziem przemocy wobec ofiar, których cierpienie zostało wystawione na widok publiczny.

3 Wystąpienie Jacques'a Derridy wydano w 1984 r. na łamach czasopisma "Diacritics". Polski przekład pod tytułem Nie, apokalipso, nie teraz! ukazał się $\mathrm{w}$ tomie $O$ apokalipsie, tłum. I. Boruszkowska, K. Wojtasik, Wydawnictwo Eperons-Ostrogi, Kraków 2018, s. $129-188$.

${ }^{4}$ Przyspieszenie zmian i ich globalna skala łączą się bezpośrednio z opanowaniem przez ludzkość energii atomowej, co według Jana Zalasiewicza dało początek nowej epoce - antropocenowi - w której człowiek okazuje się główną siłą sprawczą na poziomie geologicznym. J. Zalasiewicz i in., When Did the Anthropocene Begin? A Mid-Twentieth Century Boundary Level Is Stratigraphically Optimal, "Quaternary International" 2014, t. 30, s. 1-8.

${ }^{5} \mathrm{M}$. Blanchot, The Writing of the Disaster, tłum. A. Smock, University of Nebraska Press, Lincoln 1986, s. 1-2.

${ }^{6}$ J.-L. Nancy, After Fukushima: The Equivalence of Catastrophes, tłum. C. Mandell, Fordham University Press, New York 2015, s. 7.

${ }^{7}$ Tamże, s. 48.

${ }^{8}$ Kilka dni po awarii poziom promieniowania w mieście Fukushima, oddalonym 60 km od elektrowni, wynosił blisko 24 mikrosi- werty na godzinę, czyli więcej niż opad promieniotwórczy po próbnych wybuchach jądrowych. Por. 10 lekcji z Fukushimy w celu ochrony ludzi przed katastrofa nuklearna, red. T. Kuroda, Komitet Broszury Fukushima, Strefa Zieleni, Warszawa 2016, s. 27.

${ }^{9}$ Por. S. Yoneyama, Animism: A Grassroots Response to Socioenvironmental Crisis in Japan, w: New Worlds from Below: Informal Life Politics and Grassroots Action in Twenty-First-Century Northeast Asia, red. T. Morris-Suzuki, E. J. Soh, ANU Press, Acton 2017, s. 103-104.

${ }^{10}$ Przyjęta przez rząd japoński strategia przypomina mechanizm wyparcia, który Jean-Pierre Dupuy opisał tak: nie tylko nie "wierzymy", że [katastrofa] może się wydarzyć - choć mamy powody, by "wiedzieć", $\dot{z} e$ musi się wydarzyć - lecz nawet, gdy już do niej doszło, uznajemy, że jest skutkiem naturalnego porzadku rzeczy. J.-P. Dupuy, Pour un catastrophisme éclairé: Quand l'impossible est certain, Seuil, Paris 2002, s. 84-85.

${ }^{11}$ Por. K. Weston, Animate Planet: Making Visceral Sense of Living in a High-Tech Ecologically Damaged World, Duke University, Durham 2017, s. 86-87.

${ }^{12}$ E. Manning, Ten Propositions for Research-Creation, w: Collaboration in Performance Practice: Premises, Workings and Failures, red. N. Colin, S. Sachsenmaier, Palgrave Macmillan, Basingstoke 2016, s. 133-141.

${ }^{13}$ Znak kizuna (絆), czyli „więź”, zwyciężył w ogólnokrajowym plebiscycie na kanji $2011 \mathrm{r}$.

${ }^{14}$ J. Clarke, Apocalyptic Sublimes and the Recalibration of Distance: Doing Art-Anthropology in Post-Disaster Japan, w: Exploring Materiality and Connectivity in Anthropology and Beyond, red. P. Schorch, M. Saxer, M. Elders, UCL Press, London 2020, s. 176-177.

${ }^{15}$ K. Iwata-Weickgenannt, B. Geilhorn, Negotiating Nuclear Disaster: An Introduction, w: Fukushima and the Arts: Negotiating Nuclear Disaster, red. B. Geilhorn, K. Iwata-Weickgenannt, Routledge, New York 2017, s. 7.

${ }^{16}$ Tytuł nawiązuje do popularnej komedii Hula Girls (Hura gāru, reż. Sang-il Lee, 2006). Pisząc o filmie Hula Girls z Fukushimy, Kyoko Hirano zwróciła uwagę na łagodzenie krytycznych akcentów wobec władz państwowych i swoistą autocenzurę, co nie zdarzało się w przypadku klasycznych dokumentów zaangażowanych społecznie, które w latach 70. kręcili Shinsuke Ogawa (o protestach rolników przeciw budowie lotniska Narita) i Noriaki Tsuchimoto (o skażeniu wody w regionie Minamata). Por. K. Hirano, 311: Documenting a Catastrophe as a National Ex- 
perience, "Rethinking History” 2014, t. 18, nr 3, s. 378-390.

${ }^{17} \mathrm{Y}$. Tonaki, La banalité résiliente des catastrophe: "d'Après Fukushima" de Jean-Luc Nancy, "Rue Descartes" 2016, nr 88, s. 66-83. J.-L. Nancy, dz. cyt., s. 36-37.

${ }^{18}$ Dobrym przykładem krytycznego spojrzenia na politykę rządu japońskiego wobec ofiar katastrofy jest scena odwiedzin rodziny cesarskiej w tymczasowym ośrodku dla ewakuowanych w prefekturze Saitama. Chodziło o propagandowy wymiar wizyty, mający pokazać, że władza troszczy się o „nuklearnych uchodźców". W 2014 r. Atsushi Funahashi nakręcił drugą część filmu Daleko od Futaby (Futaba kara tōku hanarete dainibu).

${ }^{19}$ J.-L. Nancy, dz. cyt., s. 11.

${ }^{20}$ Warto wymienić trzy tytuły: Ocaleni $z$ zagłady (Hibakusha: Sekai no owari ni, 2003), Rapsodia Rokkasho (Rokkashomura rapusodi, 2006), Pszczoly i ruch obrotowy Ziemi (Mitsubachi no haoto to chikyū no kaiten, 2010). Wiele interesujących informacji na temat oddolnych inicjatyw obywatelskich majacych na celu spopularyzowanie filmów dokumentalnych na temat Fukushimy, których szanse na dystrybucję kinową ze względu na krytyczną ocenę działań rządowych są nikłe, przynosi artykuł Hideakiego Fujiki, Networking Citizens through Film Screenings: Cinema and Media in Post3.11 Social Movements, w: Media Convergence in Japan, red. P. W. Galbraith, J. G. Karlin, Kinema Club 2016, s. 60-87.

${ }^{21}$ H. Fujiki, Problematizing Life: Documentary Films on the 3.11 Nuclear Catastrophe, w: Fukushima and the Arts: Negotiating Nuclear Disaster, dz. cyt., s. 97.

${ }^{22}$ R. DiNitto, Narrating the Cultural Trauma of 3/11: The Debris of Post-Fukushima Literature and Film, "Japan Forum" 2014, t. 26, nr 3, s. 341.

${ }^{23}$ S. Sontag, Widok cudzego cierpienia, tłum. S. Magala, Karakter, Kraków 2010, s. 139.

${ }^{24}$ A. Brylska, Radioaktywne kwiaty wiśni. Relacje Japończyków ze skażonymi obszarami wokół elektrowni Fukushima Daiichi, "Teksty Drugie” 2020, nr 1, s. 148-149.

${ }^{25}$ Daniel O'Neill w interesującym odczytaniu Wspomnienia wody zwraca uwagę na fakt, że źródłem inspiracji dla Keijirō Sugi był holenderski dokument Nowa dzicz (De nieuwe wildernis, 2013, reż. Mark Verkerk). D. O'Neill, Rewilding Futures: Japan's Nuclear Exclusion Zone and Post 3.11 Eco-Cinema, "Journal of Japanese and Korean Cinema" 2019, t. 11, nr 1, s. 88.
${ }^{26}$ N. Shukin, The Biocapital of Living - and the Art of Dying - After Fukushima, „Postmodern Culture" 2016, t. 26, nr 2.

${ }^{27}$ D. Haraway, Manifest gatunków stowarzyszonych, tłum. J. Bednarek, w: Teorie wywrotowe. Antologia przekładów, red. A. Gajewska, Wydawnictwo Poznańskie, Poznań 2012, s. 242. "Gatunki stowarzyszone" to według amerykańskiej badaczki pojęcie szersze niż kategoria zwierząt towarzyszących, do których zaliczają się psy, koty i konie (czyli zwierzęta, których nie zjadamy), ponieważ obejmuje inne byty organiczne (pszczoły, kwiaty, flora bakteryjna jelit), które czynią ludzkie życie tym, czym jest.

${ }^{28} \mathrm{~W}$ perspektywie postantropocentrycznej życie nie jest ujmowane jako coś, co jest niezbywalnym prawem jednego tylko gatunku, który góruje nad wszystkimi innymi, lecz jako proces interaktywny i otwarty - stwierdza Rosi Braidotti w Po człowieku, tłum. J. Bednarek, A. Kowalczyk, Wydawnictwo Naukowe PWN, Warszawa 2014, s. 138.

${ }^{29}$ Mitsuyo Wada-Marciano w swojej analizie podkreślała, że zarówno ludzie, jak i zwierzęta, przebywając w strefie zakazanej, znaleźli się poza systemem i nadzorem władzy, w przestrzeni „deterytorialnej”. Japońska badaczka zwróciła uwagę na fakt, że na poziomie realizacyjnym dokument ten wpisuje się w tradycję cinéma vérité, pokazuje interakcje ekipy z filmowanymi zwierzętami, wyraźnie zaznacza obecność kamery, na ścieżce dźwiękowej słychać głos reżysera rozmawiającego ze swoimi współpracownikami. M. Wada-Marciano, What Animals, Women, Children, and Foreigners Can Tell Us About Fukushima, "Journal of Japanese and Korean Cinema" 2019, t. $11, \mathrm{nr} 1, \mathrm{~s} .41$.

${ }^{30}$ Wypowiedź reżysera przytaczam za materiałami prasowymi opublikowanymi na stronie internetowej filmu, http://matsurinouma.com/en/ (dostęp: 20.02.2021).

${ }^{31}$ B. Kubiak Ho-Chi, Zwierzęta a Wielkie Trzesienie Ziemi w Japonii Wschodniej w filmach dokumentalnych Shishido Daisuke i Matsubary Tamotsu, w: Zwierzęta w kulturze japońskiej, red. B. Kubiak Ho-Chi, Y. Fujii-Karpoluk, Polska Fundacja Japonistyczna, Warszawa 2018, s. 179.

${ }^{32} \mathrm{O}$ obu filmach pisała Agnieszka Kiejziewicz w artykule The Nuclear Technology Debate Returns: Narratives About Nuclear Power in PostFukushima Japanese Films, „TransMissions: The Journal of Film and Media Studies" 2017, t. 2, nr 1, s. 117-131. 
33 Pierwszy z filmów jest romantyczną opowieścią o zakochanej parze, którą rozdzieliło trzęsienie ziemi, drugi - historią młodej psycholożki zajmującej się badaniem snów u pacjentów, u których powracają koszmarne wspomnienia katastrofy. Wywiad z reżyserem został opublikowany w książce Élise Domenach Fukushima en cinéma. Voix du cinéma japonais / Fukushima in Film: Voices from Japanese Cinema, The University of Tokyo Center for Philosophy, Tōkyō 2015, s. 58-68. Krótką analizę filmu Sharing przedstawił Aaron Gerow w tekście Shinozaki Makoto's "Sharing" and Cinema After 3.11, http://www.aarongerow.com/news/shinozaki-makotos- sharing.html (dostęp: 20.02.2021).

${ }^{34} \mathrm{~W}$ styczniowym numerze czasopisma „Eiga Geijutsu" z 2013 r. opublikowano listę najlepszych i najgorszych filmów z wcześniejszego roku. W tej drugiej kategorii znalazła się Kraina nadziei, uznana za dzieło przedwczesne i nazbyt powierzchowne w porównaniu $\mathrm{z}$ dokumentami o Fukushimie. Por. M. Schilling, In the Cinematic Wake of the Fukushima Nuclear Disaster, "The Japan Times" 2015, 4 marca, https://www.japan- times.co.jp/culture/2015/03/04/films/cinematic-wake-fukushima-nuclear-disaster/ (dostęp: 17.02.2021).

${ }^{35}$ Christophe Thouny (The Land of Hope: Planetary Cartographies of Fukushima, 2012, „Mechademia: Second Arc" 2015, t. 10, s. 17-18) odczytuje Krainę nadziei jako zdecydowaną krytykę globalizacji i narodowego konsumpcjonizmu. W filmie Sono pojawiają się liczne odniesienia do autentycznych wydarzeń, jak chociażby do demonstracji przeciwników energii atomowej czy spotkań z ludźmi, którzy przeżyli katastrofę w Fukushimie i opowiadali o skutkach skażenia, wzroście zachorowań na raka tarczycy, o ukrywaniu przez rząd prawdziwych danych i utrzymywaniu społeczeństwa w niewiedzy.

${ }^{36} \mathrm{Na}$ odniesienie do strategii ,odpowiedzialności za siebie" (jikosekinin) zwróciła uwage Kristina Iwata-Weickgenannt, Gendering "Fukushima": Resistance, Self-Responsibility, and Female Hysteria in Sono Sion's "Land of Hope", w: Fukushima and the Arts: Negotiating Nuclear Disaster, dz. cyt., s. 118.

37 J. Derrida, O apokaliptycznym tonie przyjętym niedawno $w$ filozofii, w: tegoż, $O$ apokalipsie, dz. cyt., s. 125.
Krzysztof Loska
Profesor zwyczajny na Uniwersytecie Jagiellońskim, wiceprezes Polskiego Towarzystwa Badań nad Filmem i Mediami, członek Komitetu Nauk o Sztuce PAN; zajmuje się historią filmu, zwłaszcza kinem azjatyckim. Autor stu pięćdziesięciu artykułów naukowych (publikowanych w „Kwartalniku Filmowym”, „Studiach Filmoznawczych”, „Przeglądzie Kulturoznawczym”, „Ekranach”, „Kulturze Współczesnej”, „Ethosie” i in.) oraz dwunastu książek, m.in.: Dziedzictwo McLuhana - między nowoczesnościa a ponowoczesnościa (2001), Hitchcock: autor wśród gatunków (2002), David Cronenberg: rozpad ciała, rozpad gatunku (2003, wspólnie z A. Pitrusem), Tożsamość i media. O filmach Atoma Egoyana (2006), Poetyka filmu japońskiego (2009), Kenji Mizoguchi i wyobraźnia melodramatyczna (2012), Nowy film japoński (2013), Mistrzowie kina japońskiego (2015), Postkolonialna Europa: etnoobrazy zospółczesnego kina (2016). 


\section{Bibliografia}

Blanchot, M. (1986). The Writing of the Disaster (thum. A. Smock). Lincoln: University of Nebraska Press.

Braidotti, R. (2014). Po człowieku (thum. J. Bednarek, A. Kowalczyk). Warszawa: Wydawnictwo Naukowe PWN.

Brylska, A. (2020). Radioaktywne kwiaty wiśni. Relacje Japończyków ze skażonymi obszarami wokół elektrowni Fukushima Daiichi. Teksty Drugie, (1), ss. 134-151.

Clarke, J. (2020). Apocalyptic Sublimes and the Recalibration of Distance: Doing ArtAnthropology in Post-Disaster Japan. W: P. Schorch, M. Saxer, M. Elders (red.), Exploring Materiality and Connectivity in Anthropology and Beyond (ss. 172-190). London: UCL Press.

Derrida, J. (2018). O apokalipsie (tłum. I. Boruszkowska, K. Wojtasik). Kraków: Wydawnictwo Eperons-Ostrogi.

DiNitto, R. (2014). Narrating the Cultural Trauma of 3/11: The Debris of Post-Fukushima Literature and Film. Fapan Forum, 26 (3), ss. 340-36o.

Domenach, É. (2015). Fukushima en cinéma. Voix du cinéma japonais / Fukushima in Film: Voices from fapanese Cinema. Tōkyō: The University of Tokyo Center for Philosophy.

Dupuy, J.-P. (2002). Pour un catastrophisme éclairé: Quand l'impossible est certain. Paris: Seuil.

Fujiki, H. (2016). Networking Citizens through Film Screenings: Cinema and Media in Post-3.11 Social Movements. W: P. W. Galbraith, J. G. Karlin (red.), Media Convergence in Fapan (ss. 60-87). Kinema Club.

Fujiki, H. (2017). Problematizing Life: Documentary Films on the 3.11 Nuclear Catastrophe. W: B. Geilhorn, K. Iwata-Weickgenannt (red.), Fukushima and the Arts. Negotiating Nuclear Disaster (ss. 90-109). New York: Routledge.

Gerow, A. (2015). Shinozaki Makoto's Sharing and Cinema after 3.11. www.aarongerow.com/news/shinozaki-makotos-sharing.html

Haraway, D. (2012). Manifest gatunków stowarzyszonych (tłum. J. Bednarek). W: A. Gajewska (red.), Teorie wywrotowe. Antologia przektadów (ss. 241-260). Poznań: Wydawnictwo Poznańskie.

Hirano, K. (2014). 311: Documenting a Catastrophe as a National Experience. Rethinking History, 18 (3), ss. 378-390.

Iwata-Weickgenannt, K. (2017). Gendering „Fukushima”: Resistance, Self-Responsibility, and Female Hysteria in Sono Sion's „Land of Hope”. W: B. Geilhorn, K. IwataWeickgenannt (red.), Fukushima and the Arts: Negotiating Nuclear Disaster (ss. 110-126). New York: Routledge.

Iwata-Weickgenannt, K., Geilhorn, B. (2017). Negotiating Nuclear Disaster: An Introduction. W: B. Geilhorn, K. Iwata-Weickgenannt (red.), Fukushima and the Arts: Negotiating Nuclear Disaster (ss. 1-20). New York: Routledge.

Kiejziewicz, A. (2017). The Nuclear Technology Debate Returns: Narratives About Nuclear Power in Post-Fukushima Japanese Films. TransMissions: The fournal of Film and Media Studies, 2 (1), ss. 117-131.

Kubiak Ho-Chi, B. (2018). Zwierzęta a Wielkie Trzęsienie Ziemi w Japonii Wschodniej w filmach dokumentalnych Shishido Daisuke i Matsubary Tamotsu. W: B. Kubiak 
Ho-Chi, Y. Fujii-Karpoluk (red.), Zwierzęta w kulturze japońskiej. Warszawa: Polska Fundacja Japonistyczna.

Kuroda, T. (red.) (2016). 10 lekcji z Fukushimy w celu ochrony ludzi przed katastrofa nuklearna (thum. zbiorowe). Warszawa: Komitet Broszury Fukushima, Strefa Zieleni.

Manning, E. (2016). Ten Propositions for Research-Creation. W: N. Colin, S. Sachsenmaier (red.), Collaboration in Performance Practice: Premises, Workings and Failures (ss. 133-141). Basingstoke: Palgrave Macmillan.

Maurer, K. (2016). Translating Catastrophes: Yoko Tawada's Poetic Responses to the 2011 Tōhoku Earthquake, the Tsunami, and Fukushima. New German Critique, 43 (1), SS. 171-194.

Nancy, J.-L. (2015). After Fukushima: The Equivalence of Catastrophes (thum. C. Mandell). New York: Fordham University Press.

O'Neill, D. (2019). Rewilding Futures: Japan's Nuclear Exclusion Zone and Post 3.11 Eco-Cinema. Fournal of Fapanese and Korean Cinema, 11 (1), ss. 85-100.

Schilling, M. (2015). In the Cinematic Wake of the Fukushima Nuclear Disaster. The Fapan Times, 4 marca. https://www.japantimes.co.jp/culture/2015/03/04/films/cinematic-wake-fukushima-nuclear-disaster/

Shukin, N. (2016). The Biocapital of Living - and the Art of Dying - After Fukushima. Postmodern Culture, 26 (2).

Sontag, S. (2010). Widok cudzego cierpienia (tłum. S. Magala). Kraków: Karakter.

Thouny, C. (2015). The Land of Hope: Planetary Cartographies of Fukushima, 2012. Mechademia: Second Arc, 10, ss. 17-34.

Tonaki, Y. (2016). La banalité résiliente des catastrophe: „d'Après Fukushima” de Jean-Luc Nancy, Rue Descartes, 88, ss. 66-83.

Wada-Marciano, M. (2019). What Animals, Women, Children, and Foreigners Can Tell Us About Fukushima. Fournal of Fapanese and Korean Cinema, 11 (1), ss. 35-54.

Weston, K. (2017). Animate Planet: Making Visceral Sense of Living in a High-Tech Ecologically Damaged World. Durham: Duke University.

Yoneyama, S. (2017). Animism: A Grassroots Response to Socioenvironmental Crisis in Japan. W: T. Morris-Suzuki, E. J. Soh (red.), New Worlds from Below: Informal Life Politics and Grassroots Action in Twenty-First-Century Northeast Asia (ss. 99-130). Acton: ANU Press.

Zalasiewicz, J., i in. (2014). When Did the Anthropocene Begin? A Mid-Twentieth Century Boundary Level is Stratigraphically Optimal. Quaternary International, 383, Ss. 196-203.

Keywords:

Fukushima disaster; radioactive contamination; environment

\begin{abstract}
Krzysztof Loska

Life in the Shadow of a Nuclear Power Plant (Fukushima Ten Years Later)

The article discusses the films addressing the effects of radioactive contamination that occurred in March 2011 as a result of an accident at the Fukushima Daiichi nuclear power plant. Starting from the concept of disaster as perceived by
\end{abstract}


French philosophers - Jacques Derrida, Maurice Blanchot, and Jean-Luc Nancy - the author focuses on how this topic has been presented in Japanese documentaries and feature films, whose makers tried to deal with the unimaginable, confronted various ethical dilemmas, and reflected on the issue of human responsibility for the surrounding world and natural disasters caused by our activities.

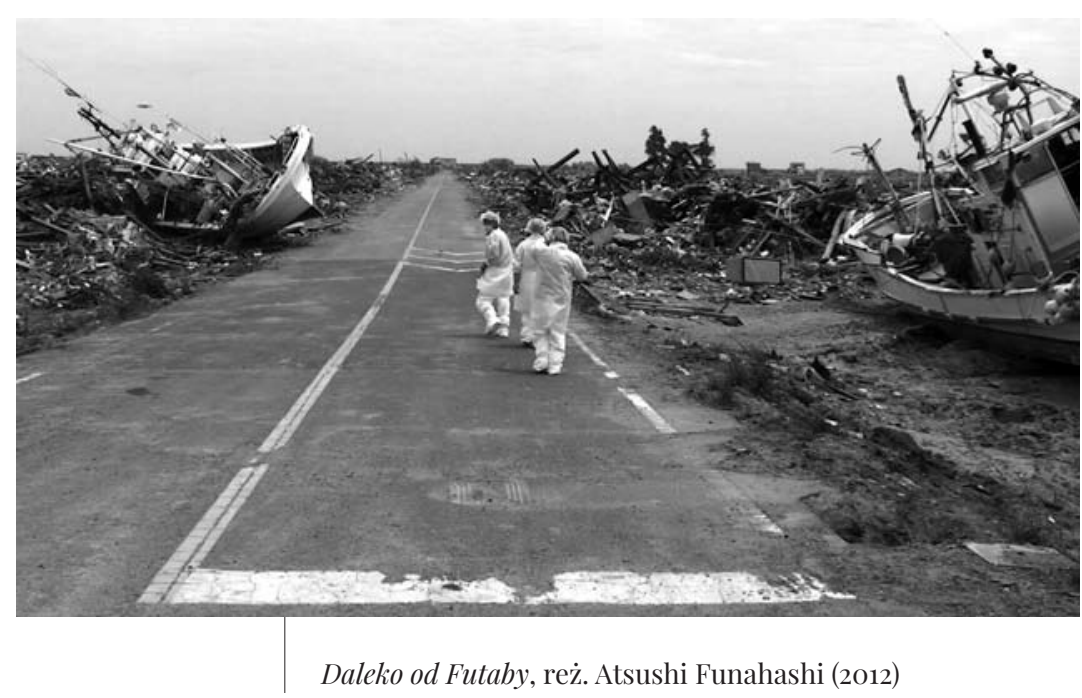

